\title{
PENGENALAN TANAMAN OBAT FAMILY ZINGIBERACEAE DAN MANFAATNYA MENGGUNAKAN AUGMENTED REALITY BERBASIS ANDROID
}

\author{
Oky Nigel Fernandarisky, Ali Mahmudi, Hani Zulfia Zahro' \\ Program Studi Teknik Informatika S1, Fakultas Teknologi Industri \\ Institut Teknologi Nasional Malang, Jalan Raya Karanglo km 2 Malang, Indonesia \\ fernandanigel@gmail.com
}

\begin{abstract}
ABSTRAK
Tanaman obat adalah tumbuhan yang banyak diketahui memiliki banyak manfaat dalam menyembuhkan atau mencegah penyakit. Tanaman obat biasanya di gunakan dalam pengobatan tradisional. Namun seiring dengan pekembangan jaman tanaman obat sering ditinggalkan. Minimnya informasi di masyarakat akan manfaat tanaman obat membuat sebagian orang lebih memilih untuk menggunakan obat kimia atau modern. Untuk saat ini mempelajari tanaman obat hanya dapat dilakukan melalui sebuah buku dan gambar yang terdapat pada buku-buku tentang tanaman obat tersebut masih disajikan dalam bentuk 2D.

Permasalahan tersebut menjadi latar belakang dilakukannya pengembangan dan pembuatan aplikasi Augmented Reality berbasis Android yang dapat digunakan untuk memvisualisasikan bentuk tanaman obat dalam bentuk objek 3D. Aplikasi ini dibangun menggunakan software Unity 2018 3.9f1 dengan menggunakan marker yang memanfaatkan Vuforia, dan objek 3D dibangun menggunakan software 3Ds Max. Data yang digunakan berdasarkan family zingiberaceae diambil dari buku Herbal Indonesia Berkhasiat Bukti Ilmiah, dan Cara Racik Vol 10 Penerbit Trubus.

Berdasarkan hasil pengujian user, menunjukkan nilai kepuasan sebanyak $77,2 \%$ dengan kriteria baik. Berdasarkan pengujian fungsi didapatkan hasil bahwa marker dapat terdeteksi dengan rentang jarak $10 \mathrm{~cm}-40 \mathrm{~cm}$.
\end{abstract}

Kata kunci : Augmented Reality, Tanaman Obat, Zingiberaceae, Android

\section{PENDAHULUAN}

\subsection{Latar Belakang}

Tanaman obat adalah salah satu makhluk hidup yang mempunyai banyak manfaat atau disebut laboratorium farmasi terlengkap. Di dalam kandungan tanaman obat tersimpan lebih dari 10.000 senyawa organik yang berkhasiat sebagai obat. Setiap tanaman obat biasanya menghasilkan senyawa metabolit sekunder yang berbeda-beda, bahkan didalam satu jenis tanaman obat memiliki lebih dari satu tanaman obat. Hasil metabolit sekunder yang aslinya bersifat toksik diisolasi dan diubah oleh industri farmasi menjadi obat bagi manusia.[1]

Tanaman obat memiliki banyak family salah satunya adalah Zingiberaceae. Zingiberaceae sering disebut temu-temuan di Indonesia dan tanaman jenis ini banyak ditemukan di tempat beriklim tropis. Fungsi utama dari tumbuhan family Zingiberaceae adalah sebagai tempat menyimpan metabolisme tertentu. Bagian tertentu tersebut ialah rimpang. Rimpang menyimpan banyak astiri dan alkaloid yang berkhasiat sebagai pengobatan.

Masyarakat pada umumnya banyak yang kurang mengetahui mengenai kegunaan tanaman obat. Karena itu masyarakat lebih memilih menggunakan obat-obatan kimia yang disarankan oleh dokter, meskipun harga obat kimia relatif mahal. Sehingga masyakarat mencari alternatif lain yang dapat menggantikan obat kimia yaitu dengan menggunakan tanaman obat sebagai obat herbal. Keunggulan penggunaan obat yang berbahan dasar tanaman obat mempunyai efek samping yang relatif kecil dibandingkan dengan obat kimia [2]. Namun pengetahuan masyarakat mengenai tanaman obat sangat minim. Untuk saat ini cara masyarakat mempelajari tanaman obat dilakukan melalui buku dan gambar yang terdapat pada buku-buku tentang tanaman obat yang masih disajikan dalam bentuk 2D dan melalui informasi dari mulut ke mulut yang tentunya belum dapat dipertanggungjawabkan kebenarannya secara ilmiah. Dengan memperhatikan bahwa kebutuhan manusia akan informasi lebih tertarik pada objek yang ditampilkan secara visual, maka penulis menganggap perlu di sampaikan informasi yang lebih menarik mengenai pengenalan tanaman obat yang dapat ditampilkan menyerupai bentuk nyata. Dalam ilmu ICT (Information Communication and Technology) permasalahan tersebut dapat diselesaikan melalui teknologi Augmented Reality sehingga objek informasi pengenalan tanaman obat tersebut dapat diinformasikan menyerupai bentuk yang sesungguhnya yang dapat ditampilkan dalam bentuk objek 3D. Aplikasi ini nantinya akan diwujudkan dalam aplikasi berbasis Android.

\subsection{Rumusan Masalah}

Berdasarkan permasalahan yang sudah dipaparkan pada latar belakang, maka dapat dirumuskan masalah sebagai berikut:

1 Bagaimana cara merancang dan mengimplementasikan aplikasi pengenalan tanaman obat berbasis android?

2 Bagaimana menerapkan teknologi Augmented Reality pada aplikasi Android sebagai pengenalan tanaman obat? 
3 Bagaimana cara mengintregasikan aplikasi pengenalan tanaman obat ke dalam smartphone $?$

\subsection{Tujuan}

Terdapat beberapa tujuan dari pembuatan aplikasi ini sebagai berikut:

1. Pengenalan tanaman obat family zingiberaceae didapatkan dengan data buku Herbal Indonesia Berkhasiat Bukti Ilmiah, dan Cara Racik Vol 10" penerbit Trubus.

2. Pengenalan tanaman obat dibangun menggunakan software Unity

3. Pengenalan tanaman obat dibuat dengan software Unity dengan build sistem operasi Android

\subsection{Manfaat}

Terdapat beberapa manfaat dari pembuatan aplikasi ini sebagai berikut :

1. Membantu pelajar, mahasiswa, dan masyarakat umum untuk mengetahui dan memahami pengenalan tanaman obat.

2. Dapat memberikan pengetahuan mengenai bentuk - bentuk tanaman obat untuk pelajar, mahasiswa, dan masyarakat umum.

3. Untuk penulis, membantu memahami fungsi Augmented Reality menggunakan marker berbasis Android dalam pembuatan pengenalan tanaman obat.

\subsection{Batasan Masalah}

Berdasarkan rumusan masalah pembuatan aplikasi ini terdapat beberapa batasan dalam pembuatan yaitu sebagai berikut:

1. Aplikasi ini berbasis Android menggunakan Single Marker.

2. Aplikasi dirancang menggunakan software Unity 2018 3.9f1.

3. Pembuatan objek 3D menggunakan aplikasi 3ds Max 2016.

4. Pada marker, dan database menggunakan Vuforia SDK.

5. Aplikasi berbahasa Indonesia.

6. Target pengguna adalah pelajar, mahasiswa, dan masyarakat umum.

7. Sumber data dari buku "Herbal Indonesia Berkhasiat Bukti Ilmiah, dan Cara Racik Vol 10 " penerbit Trubus yang berisikan mengenai nama lokal, klasifikasi ilmiah, kegunaan, dan bukti empiris tanaman obat.

8. Data yang digunakan berdasarkan famili Zingiberaceae sejumlah 10 tanaman obat yang meliputi jahe merah, kapulaga, bangle, kunci pepet, kunyit, lengkuas, temu ireng, temu kunci, temu putih, dan temulawak

\section{TINJAUAN PUSTAKA}

\subsection{Penelitian Terkait}

Penggunaan Augmented Reality (AR) dalam pembelajaran edukatif mengenai Tanaman Obat Keluarga (TOGA) dikalangan siswa SMP. Ilmu terkait TOGA yang digabungkan dengan tekhnologi yang berupa objek 3D dan desain yang menarik diharapkan menciptakan sebuah lingkungan pembelajaran yang lebih interakktif [3]

Tanaman merupakan objek yang sering dilihat di berbagai, Dan banyaknya jenis tanaman tidak semua masyarakat mengetahui informasi yang jelas mengenai tanaman tersebut. Teknologi AR membantu untuk menampilkan informasi berupa suara, dan gambar secara nyata. [4]

Augmented reality adalah suatu lingkungan yang memasukkan objek virtual 3D kedalam lingkungan nyata, Karena itu unsur realita lebih diutamakan pada sistem ini. Analisis marker based tracking adalah analisa Augmented Reality yang mrnggunakan marker atau penanda objek dua dimensi yang memiliki suatu pola yang akan dibaca komputer melalui media webcam atau kamera yang tersambung dengan komputer, merupakan ilustrasi hitam putih dengan batas hitam tebal dan latar belakang putih. [5]

Benda maya dapat menampilkan benda nyata melalui sebuah penanda atau marker. Marker merupakan penanda yang berupa kumpulan titik untuk mempermudah komputasi dari pengukuran parameter-parameter pada pengolahan citra [6]

Vuforia merupakan sebuah software development pada bidang Augmented Reality untuk memudahkan pembuatan aplikasi atau proyek mengenai augmented reality. Vuforia memanfaatkan teknologi computer vision untuk melacak dan mengenali penanda atau marker pada objek 3D sederhana seperti kotak secara realtime.[7]

\subsection{Dasar teori}

\subsubsection{Tanaman Obat}

Tanaman obat merupakan pengobatan tradisional yang aman, efektif, selektif, dan ekonomis. Tanaman obat mempunyai kegunaan untuk kuliner, pengobatan, dan bahkan aktivitas spiritual. Tanaman obat/herbal yang dibudidayakan dalam skala rumah tangga lebih sering disebut sebagai Tanaman Obat Keluarga (TOGA). [8]

Tanaman obat berdasarkan famili Zingiberaceae ini terdapat 10 objek, diantaranya adalah:

1. Temulawak

Nama Latin : Curcuma xanthorrhiza

Nama Lokal : Temulawak (Jawa), Temu Lobak (Madura), Koneng Gede (Sunda).

Kegunaan : Mengobati hepatitis, radang hati, radang empedu, radang ginjal,kurang napsu makanan, diare, wasir, melancarkan ASI, dan kolesterol tinggi.

Empiris :Temulawak merupakan salah satu keluarga Zingiberaceae yang paling sering digunakan sebagai obat. Senyawa aktif berkhasiat obat paling banyak berkumpul di dalam rimpang. Temulawak digunakan untuk mengobati

2. Kunyit Nama Latin : Curcuma longa 
Nama Lokal :Kunir (Jawa), Kunit (Kalimantan), Kakunye (Sumatera), Uinida (Sulawesi).

Kegunaan : Menurunkan tekanan darah, obat malaria, obat cacing, obat sakit perut, mengobati keseleo, memar, dan rematik.

Empiris :Rimpang kunyit digunakan untuk menurunkan tekanan darah, obat malaria, obat cacing, obat sakit perut, memperbanyak ASI, stimulan, mengobati keseleo, memar, dan rematik.

3. Jahe Merah

Nama Latin :Zingiber officinale var. rubrum Nama Lokal:Jahe (Jawa), Halia udang (Aceh)

Kegunaan :Menghangatkan badan, meluruhkan keringat, mengatasai perut kembung, mengatasi radang tenggorokan, dan megatasi nyeri otot.

Empiris :Herbal yang juga dipercaya melindungi tubuh adalah jahe merah. Khasiat Zingiberaceae officinale umumnya hanya menghangatkan badan, meluruhkan keringat mengatasi perut kembung, mengatasi radang tenggorokan,mengatasi nyeri otot.

4. Bangle

Nama Latin : Zingiber cassumanar

Nama Lokal :Bangle (Jawa), Panglai (Sunda), Padhiyang (Madura), Kunit bolai (Sumatera), Banggele (Bali)

Kegunaan :Mengobati demam, sakit kepala, batuk berdahak, perut nyeri, masuk angin, sembelit, sakit kuning, dan cacingan.

Empiris: Rimpang bangle bersifat aromatik sesuatu yang menjadi pembeda dengan keluarga Zingiberaceae lainnya. Dari bentuk fisiknya bangle tidak berbeda jauh dengan rempah-rempah anggota famili zingiberaceae lainnya.

5. Kapulaga

Nama Latin :Amomum cordamomum

Nama Lokal :Kapulogo (Jawa), Kapulagha (Madura, Bali), Gandimong (Bugis), Kapol (Sunda)

Kegunaan :Mengatasi gangguan radang tenggorokan, batuk, perut kembung, dan mual.

Empiris :Buah kapulaga biasa dipakai untuk mengatasi gangguan radang tenggorokan, batuk, perut kembung, dan mual.

6. Kunci pepet

Nama Latin : Kaempferia rotunda

Nama Lokal : Kunci pepet (Jawa), Kunci kunat (Sunda), Temu rapet (Padang)

Kegunaan : Melarutkan lemak, mencegah dan mengobati kanker, mengobati kencing manis, obat penyakit kulit, pencerah kulit, dan antioksidan.

Empiris :Rimpangnya dibuat minuman kesehatan, serbuknya diseduh air panas lalu ditambah madu atau jeruk nipis. Selain menyegarkan rimpang kunci pepet dipercaya dapat melarutkan lemak alias melangsingkan, mencegah dan mengobati kanker, kencing manis, penyakit kulit seperti eksim, pencerah kulit, dan antioksidan.

7. Lengkuas

Nama Latin : Alpinia galanga
Nama Lokal : Laos (Jawa), Laja (Sunda)

Kegunaan : Mengobati rematik, bronkitis, masuk angin, menambah nafsu makan, mencairkan dahak, kurap, flek hitam, dan menghangatkan badan.

Empiris :Lengkuas mengobati rematik, bronkitis, masuk angin, menambah nafsumakan, mencairkan dahak, gangguan limpa, pembersih darah, kurap, flek hitam membersihkan rahim setelah melahirkan, dan menghangatkan badan.

8. Temuireng

Nama Latin : Curcuma aeruginosa

Nama Lokal : Temu ireng (Jawa, Bali), Koneng hideung (Sunda), Temo ereng (Madura), Temu leteng (Makasar), Temu lotong (Bugis)

Kegunaan :Mengobati rematik, bronkitis, masuk angin, menambah nafsu makan, mencairkan dahak, kurap, flek hitam, dan menghangatkan badan.

Empiris :Rimpang berguna mengatasi gangguan pencernaan seperti perut mulas dan sakit perut, sesak napas, sariawan, menambah nafsu makan.

9. Temukunci

Nama Latin : Boesenbergia Rotunda

Nama Lokal :Koncih (Sumatera), tamu kunci (Minangkabau), konce (Madura), kunci (JawaTengah), dumu kunci (Bima), tamu konci (Makasar).

Kegunaan : Temukunci dicampurkan ketika memasak sayur bayam, tujuannya untuk mentralisir kadar purin yang cukup tinggi dalam bayam. Di Thailand, rimpang temu kunci bisa digunakan sebagai bumbu masak

Empiris :Secara umum, masyarakat menggunakan rimpang temukunci sebagai peluruh dahak atau untuk menanggulangi batuk, peluruh kentut, penambah nafsu makan, menyembuhkan sariawan, dan pemacu keluarnya air susu ibu (ASI) Minyak asiri rimpang temukunci juga berkhasiat antibakterí pada pertumbuhan Entamoeba coli, Staphyllococus aureus dan Candida albicans.

10. Temuputih

Nama Latin : Curcuma zedoaria

Nama Lokal : Kunyit putih (Jawa, Bali), Koneng bodas (Sunda)

Kegunaan :Mengobati gangguan menstruasi, melancarkan pengularan darah haid, dan mengurangi rasa nyeri

Empiris : Temuputih kerap disertakan untuk mengobati gangguan menstruasi, rimpangnya melancarkan pengeluaran darah haid dan mengurangi rasa nyeri.

\subsubsection{Augmented Reality}

Augmented Reality merupakan konsep penggabungan dunia virtual ke dalam dunia nyata. Penciptaan dunia virtual dilakukan untuk membangkitkan persepsi pengguna untuk memahami informasi dari objek yang dikenali. Augmented 
Reality terbagi menjadi 2 metode yaitu marker dan markerless. Marker adalah penanda khusus yang dibuat seperti sebuah gambar atau barcode, sedangkan markerless adalah penanda yang berhubungan dengan objek secara langsung. [9]

\subsubsection{Image Target}

Image Target adalah suatu gambar yang bisa dilacak dan dideteksi oleh Vuforia SDK. Vuforia SDK mengenali image target dengan membandingkan fitur yang ada pada gambar fisik dengan gambar yang ada didalam database aplikasi. Ketika gambar sudah terdeteksi, Vuforia SDK melacak gambar yang ada pada sudut pandang kamera. Fitur yang dilacak oleh Vuforia SDK adalah detail berbentuk sudut pada gambar. Berikut adalah kriteria gambar yang akan digunakan sebagai image target antara lain: [10]

1. Gambar harus memiliki format 8 atau 16-bit dan berekstensi JPG atau PNG.

2. Gambar yang berformat JPG harus memiliki warna RGB atau grayscale

3. Memiliki resolusi minimal 320 pixel.

4. Memiliki ukuran maksimal $2 \mathrm{MB}$.

5. Gambar tidak memiliki pola yang berulang.

Setelah diunggah, secara otomatis gambar mendapatkan implementasi algoritma yang dibuat khusus oleh vuforia sehingga fitur-fitur bisa terlihat dengan jelas. [10]

\section{METODE PENELITIAN}

\subsection{Blok Diagram Sistem}

Blok diagram adalah diagram dari sebuah sistem, di mana bagian utama atau fungsi yang diwakili oleh blok dihubungkan dengan garis, yang menunjukkan hubungan dari blok. Proses kerja pada aplikasi pengenalan tanaman obat ditunjukkan pada Gambar 1.
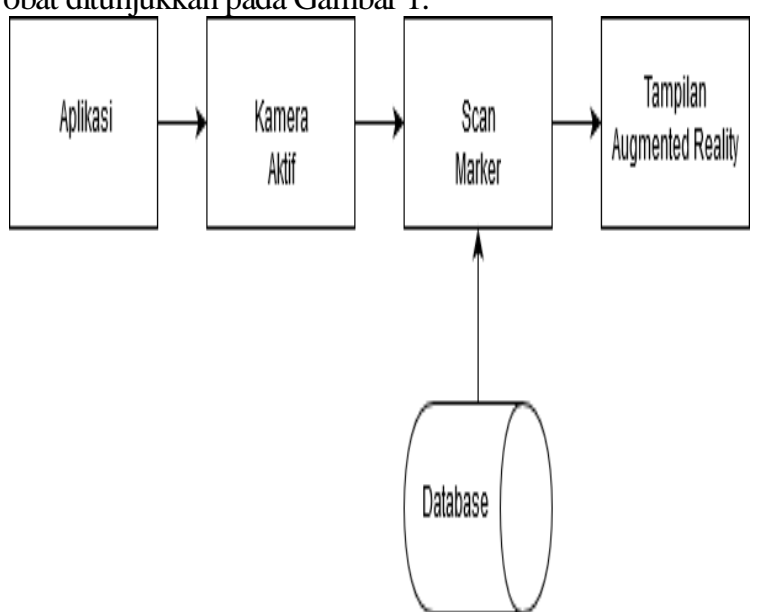

Gambar 1 Blok diagram

\subsection{GUI Menu}

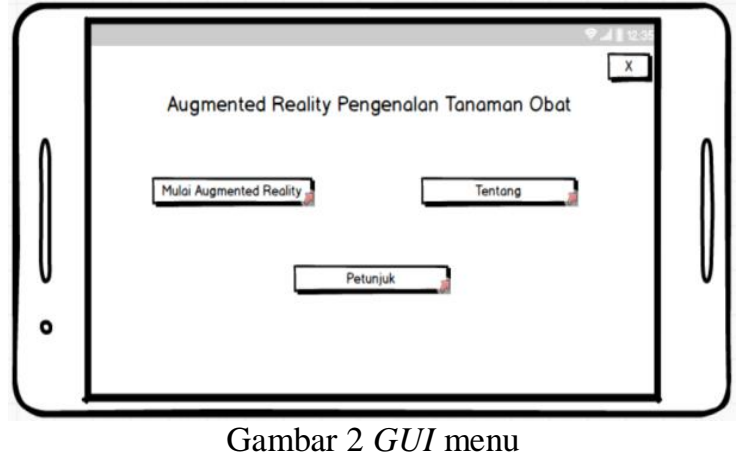

Dilihat di gambar 2 GUI menu utama mempunyai susunan dan tata letak menu aplikasi pengenalan tanaman obat tersebut memiliki struktur menu diantaranya judul dan 4 button. Button pertama yakni Augmented Reality yakni tampilan bentuk tanaman obat secara 3D, Button kedua yakni bantuan dimana aplikasi akan memberitahui user cara penggunaan aplikasi. Button kelima yakni About dimana tertulis biodata pengembang. Dan button keenam yakni button tutup untuk menutup aplikasi.

\subsection{Struktur Menu}

Pada gambar 3 Sturktur Menu terdiri atas 4 menu yang berisi scan marker, tentang, petunjuk, dan keluar. Scan marker untuk memunculkan objek 3D. Tentang berisikan biodata pembuat dan informasi aplikasi. Petunjuk berfungsi untuk tentang penggunaan aplikasi. Keluar untuk menutup aplikasi ditunjukkan pada Gambar 3.

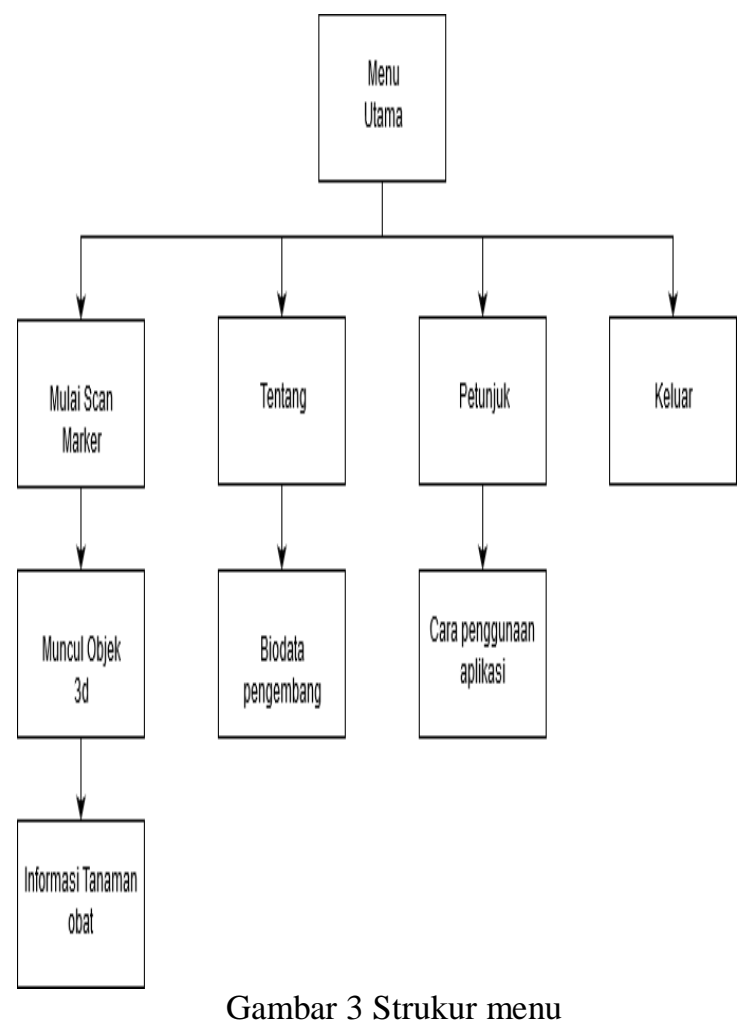

3.4 Flowchart Aplikasi 
Flowchart aplikasi dari pengenalan tanaman obat menggunakan Augmented Reality berbasis android dimana alur kerja berjalannya aplikasi tersebut ditunjukkan Gambar 4.

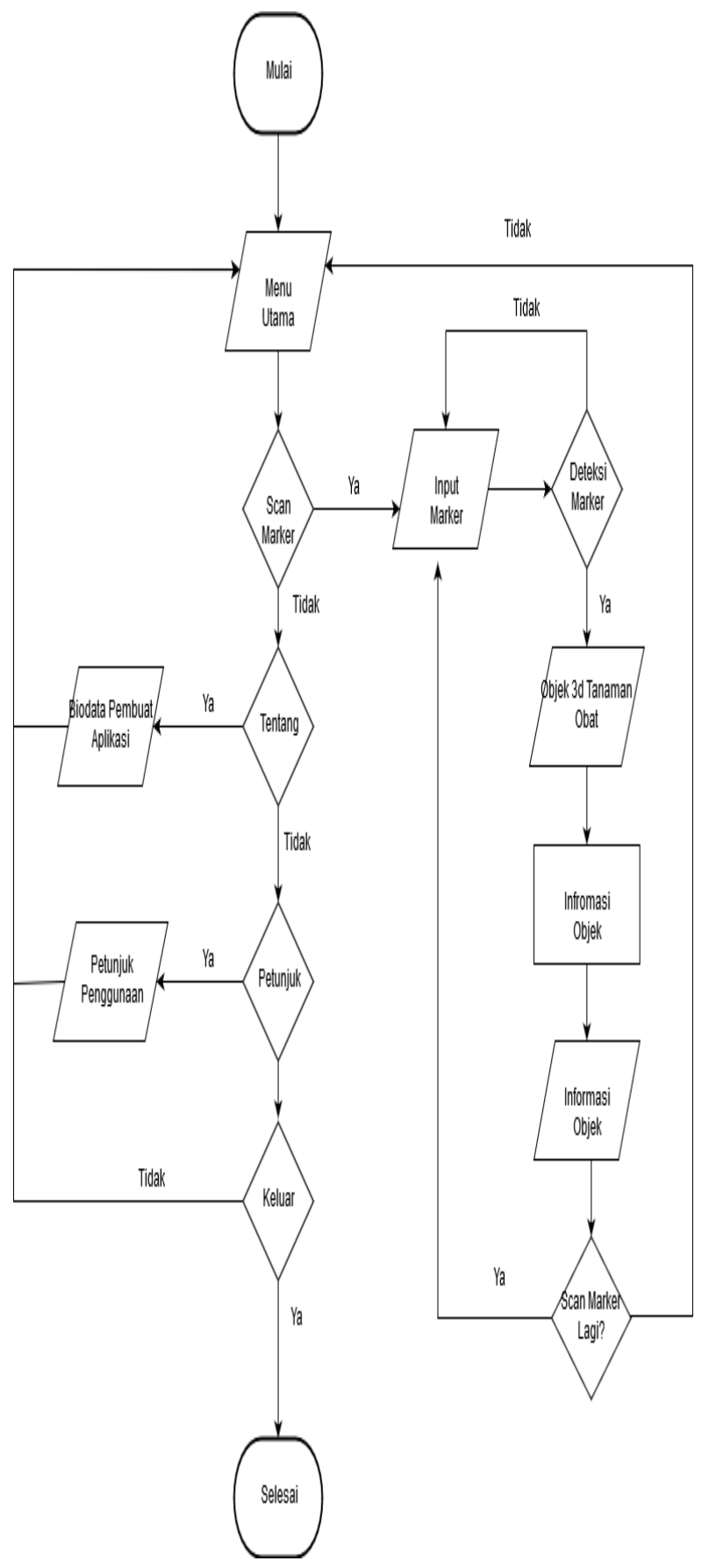

Gambar 4 Flowchart aplikasi

\subsubsection{Flowchart Augmented Reality}

Flowchart metode dari proses Augmented Reality pada aplikasi pengenalan tanaman obat menggunakan Augmented Reality berbasis android ditunjukkan pada gambar 5 .

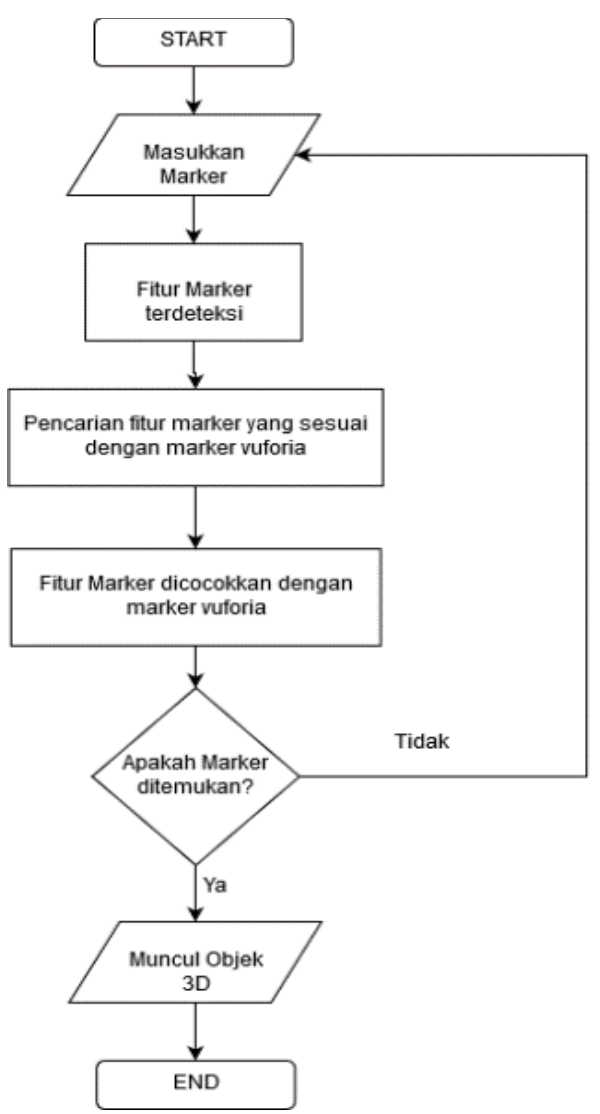

Gambar 5 Flowchart Augmented Reality

\section{HASIL DAN PEMBAHASAN}

4.1 Pengujian Menu Utama

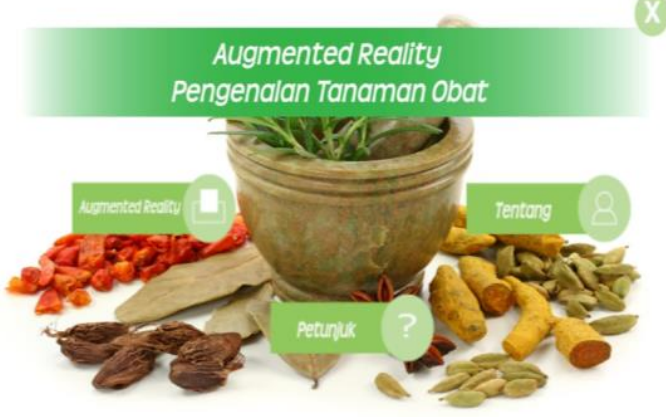

Gambar 6 Pengujian menu utama

Pada Gambar 6 Pengujian menu utama menunjukkan sebuah tampilan aplikasi dimana fitur dan tombol menu, tombol augmented reality, tombol tentang, tombol petunjuk dan tombol keluar.

4.2 Pengujian Menu Augmented Reality

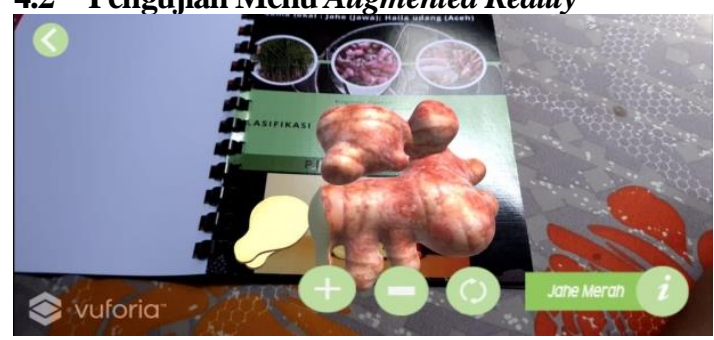

Gambar 7 Pengujian menu Augmented Reality 
Pada Gambar 7 Pengujian augmented reality diatas menunjukkan tampilan menu seperti augmented reality, tampilan tersebut menampilkan objek 3 dimensi tanaman obat dan 5 tombol, yakni tombol kembali tombol Zoom In, Zoom Out, tombol rotasi, dan tombol informasi.

\subsection{Pengujian Informasi pada menu Augmented} Reality

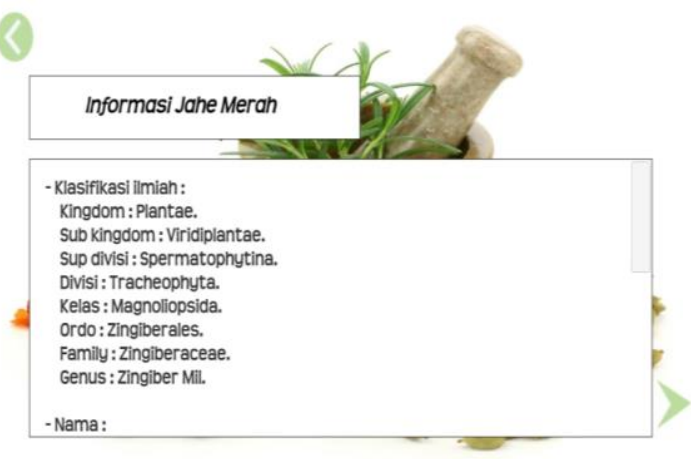

Gambar 8 Pengujian informasi pada menu Augmented Reality

Pada Gambar 8 Pengujian diatas menunjukkan tampilan sub menu dari Augmented Reality, tampilan tersebut menunjukkan manfaat tiap objek tanaman obat.

\subsection{Pengujian Menu Tentang}

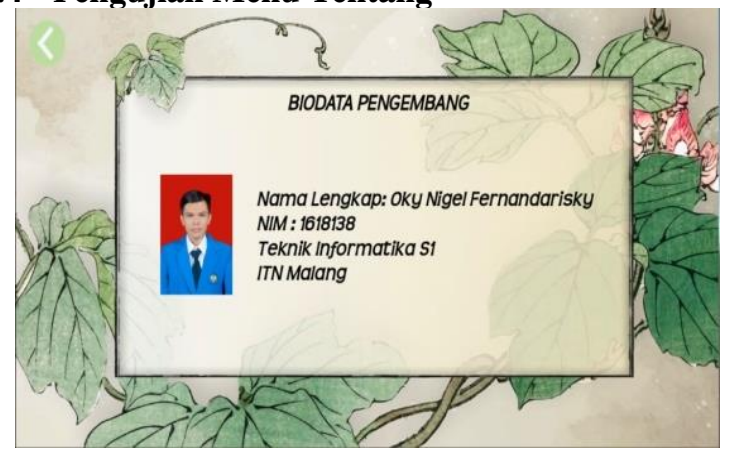

Gambar 9 Pengujian menu tentang

Pada Gambar 9 Pengujian tentang diatas menunjukkan tampilan menu tentang, tampilan tersebut menunjukkan informasi profil pengembang atau pembuat aplikasi.

\subsection{Pengujian Menu Petunjuk}

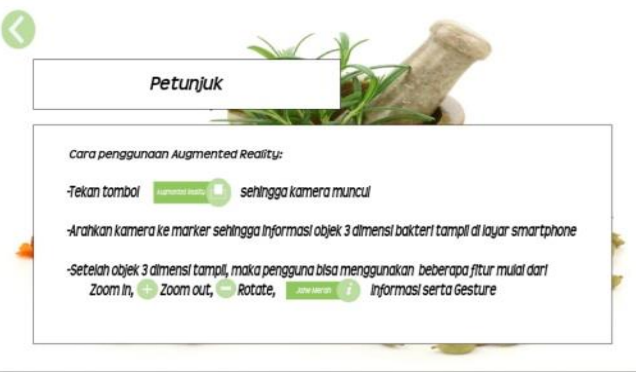

Gambar 10 Pengujian menu petunjuk
Pada Gambar 10 Pengujian petunjuk diatas menunjukkan tampilan menu petunjuk, tampilan tersebut menunjukkan informasi pertunjuk penggunaan fitur Augmented reality.

\subsection{Pengujian Perangkat Sistem Operasi Android}

Berikut adalah hasil uji coba aplikasi Pengenalan Tanaman Obat Family Zingiberaceae Menggunakan Augmented Reality Berbasis Android pada beberapa perangkat smartphone pada tabel 1 .

Tabel 1 Pengujian sistem operasi android

\begin{tabular}{|c|c|c|c|c|c|}
\hline \multirow[t]{2}{*}{ Merk } & \multirow{2}{*}{$\begin{array}{l}\text { Sistem } \\
\text { Operasi }\end{array}$} & \multirow[t]{2}{*}{ Prosessor } & \multirow[t]{2}{*}{ RAM } & \multicolumn{2}{|c|}{ Hasil Uji Coba } \\
\hline & & & & $\begin{array}{l}\text { Status } \\
\text { Install }\end{array}$ & $\begin{array}{l}\text { Waktu } \\
\text { load } \\
\text { aplikasi }\end{array}$ \\
\hline $\begin{array}{l}\text { Redmi } \\
\text { Note } 4\end{array}$ & $\begin{array}{c}\text { Nougat } \\
7.0\end{array}$ & $\begin{array}{c}\text { Snapdragon } \\
650\end{array}$ & $3 \mathrm{~GB}$ & $\checkmark$ & 9 detik \\
\hline $\begin{array}{l}\text { Samsung } \\
\text { A5 }\end{array}$ & $\begin{array}{c}\text { Oreo } \\
8.0\end{array}$ & $\begin{array}{c}\text { Exynos } \\
7870\end{array}$ & $3 \mathrm{~GB}$ & $\checkmark$ & 7 detik \\
\hline $\begin{array}{l}\text { Redmi } \\
\text { Note } 3 \\
\text { Pro }\end{array}$ & $\begin{array}{c}\text { Nougat } \\
7.0\end{array}$ & $\begin{array}{c}\text { Snapdragon } \\
625\end{array}$ & $3 \mathrm{~GB}$ & $\checkmark$ & $\begin{array}{c}11 \\
\text { detik }\end{array}$ \\
\hline $\begin{array}{l}\text { Samsung } \\
\text { S10+ }\end{array}$ & Pie 9.0 & $\begin{array}{c}\text { Exynos } \\
9820\end{array}$ & $8 \mathrm{~GB}$ & $\checkmark$ & 3 detik \\
\hline $\begin{array}{l}\text { Xiaomi } \\
\text { Mi Mix }\end{array}$ & $\begin{array}{c}\text { Oreo } \\
8.0\end{array}$ & $\begin{array}{c}\text { Snapdragon } \\
821\end{array}$ & $6 \mathrm{~GB}$ & $\checkmark$ & 3 detik \\
\hline $\begin{array}{l}\text { Keteranga } \\
\checkmark \text { : Berha } \\
* \text { : Gagal }\end{array}$ & $\begin{array}{l}\text { ter-insta } \\
\text {-install }\end{array}$ & & & & \\
\hline
\end{tabular}

\subsection{Pengujian Deteksi Rentang Jarak}

Pada augmented reality, jarak adalah salah satu faktor yang penting terhadap proses mendeteksi marker. Untuk mendeteksi marker tergantung posisi kamera, Ketika jarak kamera dan marker semakin jauh maka semakin buruk juga kualitas pengenalan marker yang dapat di proses oleh kamera. Pengujian jarak ini bertujuan untuk melihat selisih jarak yang optimal agar marker dapat terdeteksi dengan baik.

Pengujian rentang jarak dilakukan dengan 3 rentangan jarak yakni $10 \mathrm{~cm}, 20 \mathrm{~cm}, 30 \mathrm{~cm}, 40 \mathrm{~cm}$, dan $50 \mathrm{~cm}$. 


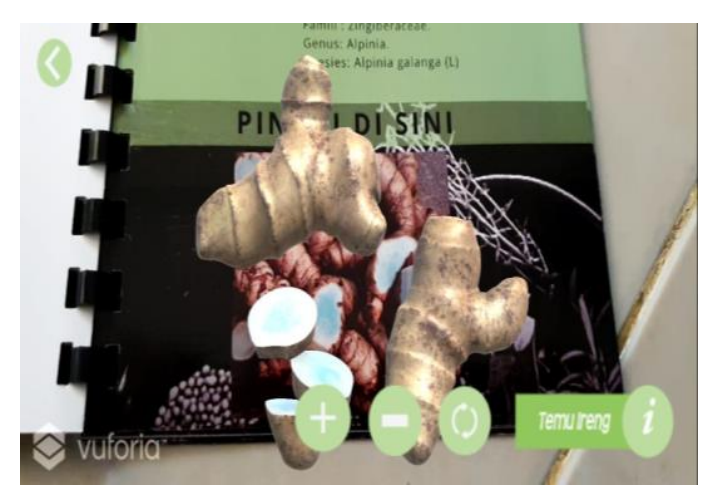

Gambar 11 jarak $10 \mathrm{~cm}$

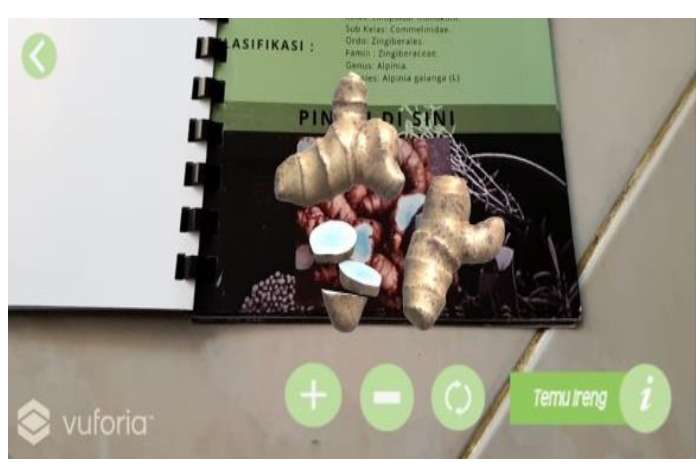

Gambar 12 jarak $20 \mathrm{~cm}$

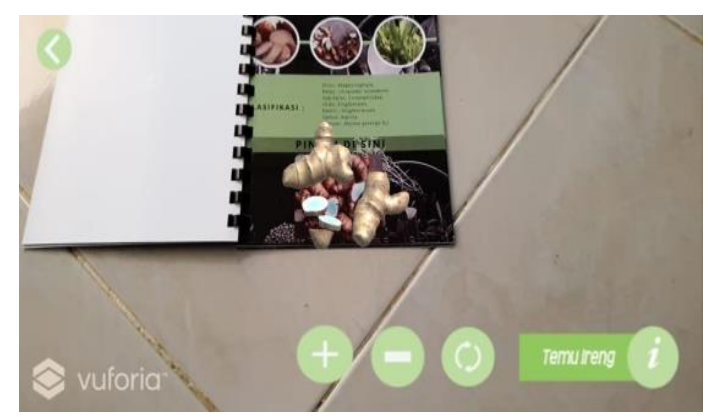

Gambar 13 jarak $30 \mathrm{~cm}$

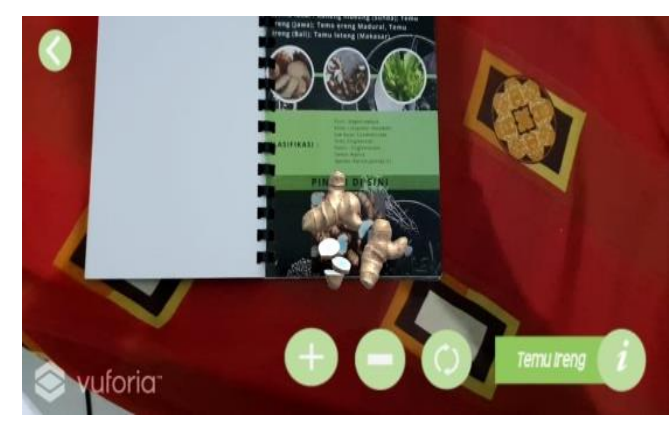

Gambar 14 jarak $40 \mathrm{~cm}$

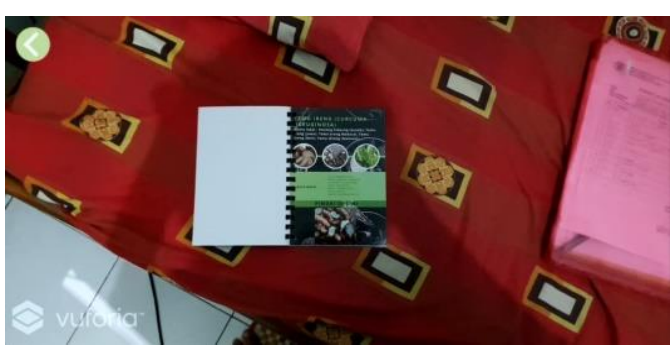

Gambar 15 jarak $50 \mathrm{~cm}$

Tabel 2 Pengujian jarak marker

\begin{tabular}{|c|c|c|c|c|c|c|}
\hline \multirow[t]{2}{*}{ No. } & \multirow{2}{*}{$\begin{array}{c}\text { Nama Tanaman } \\
\text { Obat }\end{array}$} & \multicolumn{5}{|c|}{ Keterangan } \\
\hline & & $10 \mathrm{~cm}$ & $20 \mathrm{~cm}$ & $30 \mathrm{~cm}$ & $40 \mathrm{~cm}$ & $50 \mathrm{~cm}$ \\
\hline 1. & Temu Putih & 1 detilk & 1 detik & 3 detik & 5 detilk & . \\
\hline 2. & Temu Lawak & 1 detik & 1 detik & 1 detik & 2 detik & . \\
\hline 3. & Temu Ireng & 1 detilk & 1 detik & 1 detik & 2 detik & . \\
\hline 4. & Lengkuas & 1 detik & 1 detik & 3 detilk & 5 detik & . \\
\hline 5. & Kunyit & 1 detilk & 1 detik & 3 detik & 5 detik & . \\
\hline 6. & Kunci Pepet & 1 detik & 1 detik & 1 detik & 5 detik & . \\
\hline 7. & Kapulaga & 1 detik & 1 detik & 1 detik & 2 detik & . \\
\hline 8. & Temu Kunci & 1 detik & 1 detik & 3 detik & 5 detik & . \\
\hline 9. & Bangle & 1 detik & 1 detik & 1 detik & 2 detik & . \\
\hline 10. & Jahe Merah & 1 detik & 1 detik & 3 detik & 5 detik & . \\
\hline $\begin{array}{l}\text { Kete } \\
\text { Tam } \\
\text { Tam } \\
\text { Tida }\end{array}$ & $\begin{array}{l}\text { langan: } \\
\text { pil cepat : } 1-2 \text { detik } \\
\text { pill lama : } 3-5 \text { detik } \\
\text { k tampil :- }\end{array}$ & & & & & \\
\hline
\end{tabular}

Dilihat dari tabel 2 Uji coba marker menggunakan 5 rentang jarak yakni jarak $10 \mathrm{~cm}, 20$ $\mathrm{cm}, 30 \mathrm{~cm}, 40 \mathrm{~cm}$, dan $50 \mathrm{~cm}$. Dengan hasil rentang jarak $10 \mathrm{~cm}, 20 \mathrm{~cm}, 30 \mathrm{~cm}$, dan $40 \mathrm{~cm}$ semua marker dapat terdeteksi. Tetapi dengan jarak $50 \mathrm{~cm}$ semua marker tidak dapat mendeteksi objek. 


\subsection{Pengujian Cahaya}

Tabel 3 Pengujian cahaya

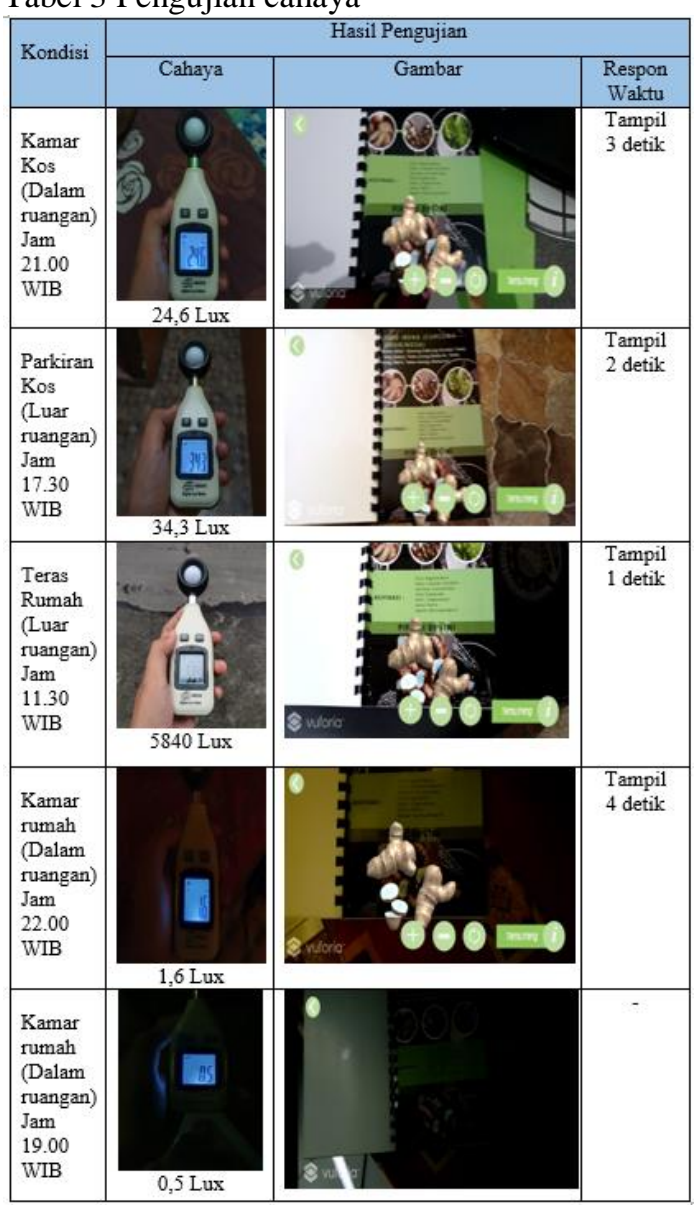

Dilihat dari Tabel 3 Didapatkan hasil pengujian semua marker dapat terdeteksi dengan rentang cahaya 0,6-5840 lux. Sedangkan cahaya 0,5 lux tidak mendeteksi objek 3d. Semakin terang cahaya maka semakin mudah untuk mendeteksi marker, namun semakin gelap cahaya maka semakin susah untuk mendeteksi marker

\subsection{Pengujian User}

Tabel 4 Pengujian User

\begin{tabular}{|l|l|c|c|c|}
\hline \multirow{2}{*}{ No. } & \multicolumn{1}{|c|}{ Pertanyaan } & \multicolumn{3}{|c|}{ Respond user } \\
\cline { 3 - 5 } & & Baik & $\begin{array}{c}\text { Cukup } \\
\text { Baik }\end{array}$ & Kurang \\
\hline 1. & $\begin{array}{l}\text { Bagaimana } \\
\text { tampilan menu } \\
\text { utama pada } \\
\text { aplikasi } \\
\text { pengenalan } \\
\text { tanaman obat? }\end{array}$ & 20 & 5 & 0 \\
\hline 2. & $\begin{array}{l}\text { Bagaimana } \\
\text { tampilan menu } \\
\text { tentang pada } \\
\text { aplikasi } \\
\text { pengenalan } \\
\text { tanaman obat? }\end{array}$ & 17 & 8 & 0 \\
\hline 3. & $\begin{array}{l}\text { Bagaimana } \\
\text { tampilan menu }\end{array}$ & 22 & 3 & 0 \\
\hline
\end{tabular}

\begin{tabular}{|c|c|c|c|c|}
\hline \multirow[t]{2}{*}{ No. } & \multirow[t]{2}{*}{ Pertanyaan } & \multicolumn{3}{|c|}{ Respond user } \\
\hline & & Baik & $\begin{array}{c}\text { Cukup } \\
\text { Baik }\end{array}$ & Kurang \\
\hline & $\begin{array}{l}\text { petunjuk pada } \\
\text { aplikasi } \\
\text { pengenalan } \\
\text { tanaman obat? }\end{array}$ & & & \\
\hline 4. & $\begin{array}{l}\text { Bagaimana } \\
\text { informasi yang } \\
\text { disampaikan pada } \\
\text { Augmented } \\
\text { Reality di aplikasi } \\
\text { pengenalan } \\
\text { tanaman obat? }\end{array}$ & 19 & 6 & 0 \\
\hline 5. & $\begin{array}{l}\text { Bagaimana objek } \\
\text { tanaman obat } \\
\text { pada menu } \\
\text { Augmented } \\
\text { Reality yang } \\
\text { ditampilkan pada } \\
\text { aplikasi } \\
\text { pengenalan } \\
\text { tanaman obat? }\end{array}$ & 21 & 4 & 0 \\
\hline 6. & $\begin{array}{l}\text { Bagaimana } \\
\text { tombol zoom in } \\
\text { pada menu } \\
\text { Augmented } \\
\text { Reality di aplikasi } \\
\text { pengenalan } \\
\text { tanaman obat? }\end{array}$ & 22 & 3 & 0 \\
\hline 7. & $\begin{array}{l}\text { Bagaimana } \\
\text { tombol zoom out } \\
\text { pada menu } \\
\text { Augmented } \\
\text { Reality di aplikasi } \\
\text { pengenalan } \\
\text { tanaman obat? }\end{array}$ & 16 & 9 & \\
\hline 8. & $\begin{array}{l}\text { Bagaimana } \\
\text { tombol rotate } \\
\text { pada menu } \\
\text { Augmented } \\
\text { Reality di aplikasi } \\
\text { pengenalan } \\
\text { tanaman obat? }\end{array}$ & 20 & 5 & 0 \\
\hline 9. & $\begin{array}{l}\text { Bagaimana } \\
\text { gesture pada } \\
\text { menu Augmented } \\
\text { Reality di aplikasi } \\
\text { pengenalan } \\
\text { tanaman obat? }\end{array}$ & 17 & 8 & 0 \\
\hline 10 & $\begin{array}{l}\text { Bagaimana } \\
\text { kemudahan } \\
\text { penggunaan } \\
\text { aplikasi } \\
\text { pengenalan } \\
\text { tanaman obat? }\end{array}$ & 19 & 6 & 0 \\
\hline Total & & 193 & 57 & 0 \\
\hline
\end{tabular}




$$
\begin{array}{ll}
\text { Baik } & =(193 / 250) * 100 \%=77,2 \% \\
\text { Cukup } & =(57 / 250) * 100 \%=22,8 \% \\
\text { Kurang } & =(0 / 250) * 100 \%=0 \%
\end{array}
$$

Dilihat dari Tabel 4 Dari penjelasan di atas dari 25 responden menyatakan Baik sebanyak 77,2\%, sedangkan yang menyatakan Cukup sebanyak 22,8\%.

\section{KESIMPULAN DAN SARAN \\ 5.1 Kesimpulan}

Setelah dilakukannya pemebuatan dan pengujian aplikasi Pengenalan Tanaman Obat Family Zingiberaceae Menggunakan Augmented Reality Berbasis Android, maka dapat ditarik kesimpulan sebagai berikut:

1. Dari 25 respoden yang terdiri dari pelajar, mahasiswa, dan masyarakat umum menujukkan nilai kepuasan sebanyak 77,2\% dengan kriteria baik.

2. Aplikasi dapat dijalankan dengan sistem operasi Nougat 7.0, prosessor Snapdragon 625, dan RAM 3 GB.

3. Marker dapat terdeteksi dengan rentang jarak 10 $\mathrm{cm}$ hingga $40 \mathrm{~cm}$.

4. Marker dapat terdeteksi dengan kondisi cahaya 0,6 lux hingga 5840 lux.

\subsection{Saran}

Berdasarkan peneltian yang telah dilakukan maka penulis dan peneliti dapat memberikan saran untuk pengembangan dan perbaikan kedepannya karena penelitian ini masih terdapat banyak kekurangan, sehingga perlu ada perbaikan sebagai berikut:

1. Desain objek 3D tanaman obat family zingiberaceae yang lebih detail pada unsur teksurnya.

2. Penambahan objek 3D tanaman obat dengan family yang lainnya

\section{DAFTAR PUSTAKA}

[1] Tim Trubus. 2012. Herbal Indonesia Berkhasiat Vol. 10. PT Trubus Swadaya.

[2] Widaryanto Eko, Azizah Nur. 2018. PERSPEKTIF TANAMAN OBAT BERKHASIAT (Peluang, Budidaya, Pengolahan Hasil, dan Pemanfaatan). UB Press.

[3] Annisa F, Kusuma A, Fuad A (2018). 3D MODELLING AUGMENTED REALITY FOR TOGA PLANTS. Jurnal Teknologi dan Terapan Bisnis. ISSN(p): 2615-8817

[4] Nunditya M D, Somantri, Christyono (2017). Aplikasi Naturar Pergerakan Tanaman berbasis Augmented Reality pada perangkat Bergerak Android. Vol 6, No.2, Juni 2017. ISSN: 23029927,241

[5] Wiguna (2019). Pengenalan Alat Musik Tradisional Indonesia Menggunakan Augmented Reality. JATI. Vol No.1 Maret 2019

[6] Sembiring B, Sapriadi (2016). Rancang Bangun dan Analisis Aplikasi Augmented Reality pada Produk Furniture. Jurnal Integrasi. Vol 8, No. 1 April 2016. ISSN:2085-3858

[7] Apriyani E M, Gustianto R (2015). Augmented Reality Sebagai Alat Pengenalan Hewan Purbakala dengan Animasi 3D Menggunakan Metode Single Marker. Vol 7 No. 1 Mei 2015

[8] Putra Satria. 2015. Kitab Herbal Nusantara. Kata Hati. Yogyakarta.

[9] Saurina Nia. 2016. Pengembangan Media Pembelajaran Untuk Anak Usia Dini Menggunakan Augmented Reality. Jurnal IPTEK. Vol 20 No. 1 Mei 2016

[10] Ramdhan K, Nurhazanah. 2017. Aplikasi Media Pembelajaran Tulang Manusia Menggunakan Augmented Reality (AR) Berbasis Android. Jurnal Teknik Informatika dan Sistem Informasi Vol. 3 No.3. 2443-2229. 